\title{
(Re)categorization as Resistance: Civil Society Mobilizations Around the Preah Vihear Temple
}

\author{
Mikael Baaz ${ }^{1} \cdot$ Mona Lilja ${ }^{2,3}$
}

Published online: 9 November 2016

(C) The Author(s) 2016. This article is published with open access at Springerlink.com

\begin{abstract}
This paper deals with civil society mobilizations and resistance in relation to a world heritage site - the ninth-century Khmer temple Preah Vihear, which is located in the northern province of Cambodia and borders eastern Thailand. In particular, the paper explores resistance in terms of (re)categorizations from a historical and discursive-materialistic perspective. The field of resistance studies has mainly been preoccupied with entities such as texts, signs, symbols, identity, and language. In this article, however, we bring in physical and material entities in order to display the ways in which matter is of importance in the (re)construction of discourses and thereby for resistance.
\end{abstract}

Keywords Resistance $\cdot$ Cambodia $\cdot$ Nationalism $\cdot$ Materialism $\cdot$ Discourses $\cdot$ Preah Vihear Temple

\section{Introduction}

The Preah Vihear Temple (PVT) — which was originally a Hindu temple but later converted into a Buddhist temple - is situated on the top of a steep cliff in the Dangrek Mountain range on the border between Cambodia and Thailand. The ancient temple, which was built during the first half of the Angkor or Khmer Empire (scholars usually date the Angkorean period between AD 802 and 1431), has been at the core of a difficult and prolonged border conflict between the two neighboring countries for more than a century (Kasetsiri et al. 2013, p. 23).

In 2008, despite the delicate nature of the matter as well as protests from Thailand, the United Nations Educational, Scientific and Cultural Organization (UNESCO) decided to list the PVT as a 'World Heritage' site. Following this decision, new disturbances broke out. Thus,

Mona Lilja

mona.lilja@gu.se

1 Department of Law, University of Gothenburg, Gothenburg, Sweden

2 School of Global Studies, University of Gothenburg, Gothenburg, Sweden

3 Department of Social and Psychological Studies, Karlstad University, Karlstad, Sweden 
the PVT conflict is not only between two governments where politicians, diplomats, and military troops are involved, but it also involves other agents such as various supranational organizations and, not the least, various local civil society actors who act very heterogeneously as both supporters of the conflict, as well as peace builders. For example, on 15 July 2008, three members of the Dharmayatra, which claims to be a Buddhist peace pilgrimage group, crossed the Cambodian border in an attempt to (re)raise the Thai flag over the disputed area and demanded the return of the PVT to Thailand. According to Cambodian sources, the trespassing led to Thai troops crossing the border to 'help' the intruders (Khmerization, 2014). By consequence, the tension between the two countries was exacerbated. This is just one example of how various civil society actors in both Cambodia and Thailand have fueled the conflict since the temple was awarded heritage status.

However, and more importantly for this paper, in recent years, there has also been resistance that promotes peace and reconciliation rather than conflict and extreme nationalistic discourses. Many civil society actors try to promote and establish less 'dangerous' truths in regard to the temple that challenge various mainstream views. This paper deals with civil society mobilizations and resistance in relation to the PVT from a historical and discursivematerialistic perspective.

There has recently been an increased interest in 'matter' within social sciences. The research produced so far that departs from this (new) 'material turn', however, has not explicitly embraced relations of power and resistance. Resistance studies has also not been inspired or informed by the material turn; instead, resistance studies has been preoccupied with entities such as texts, signs, symbols, identity, and language (Törnberg, 2013). This paper seeks to fill this gap in research by displaying how matter makes resistance possible, thus entangling power, resistance, and materiality. The question in focus is as follows: How is performed resistance articulated in relation to matter, current discourses, and the construction of history? In particular, we focus on 'resistance' in terms of (re)categorizations that are performed in the historical and discursive-material nexus of the PVT. By this, we bring in physical and material entities in order to display the ways in which matter is of importance in discursive production and for resistance. Thereby, this paper will contribute to, mainly theoretically but also empirically, our knowledge of peace-building resistance in general and the practice of it in relation to the PVT conflict in particular.

When speaking about 'resistance' in this paper, we have in mind resistance that manifests in the negotiations of what people experience as generally held 'truths'. When discussing this kind of 'subtle' resistance, we depart from the works of Paul Ricoeur (1976) who argues that there is more meaning assigned to a symbol than the literal signification. This inspires us to argue that (re)categorization can occur while the real is represented in a more literal way that abandons 'contextual readings' in relation to different nationalistic discourses. The practices of (re)categorization can be seen as a deconstructing strategy that challenges power-loaded nationalistic discourses and the cultural order - in this case, in both Cambodia and Thailand.

The remainder of the paper proceeds as follows: In the next section, we introduce the empirical material and discuss some methodological considerations. In section three, we elaborate on the context of the PVT conflict by providing a short historical background. Sections four and five discuss what we consider to be relevant (previous and current) research where the aim is to position and justify our theoretical contribution in relation to the 'research front'. Among other things, we discuss the linguistic and material turn, as well as the different levels of signification. In section six, we analyze our empirical material from the developed theoretical framework and then summarize our conclusions in the final section. The focus is on 
resistance and civil society from a discursive-material perspective, as well as how peacebuilding civil society-based resistance can be understood from a poststructural reactivating of the materialistic aspect of social analysis.

\section{Some Notes on Materials and Methods}

This paper is written within a broader research project on the Preah Vihear temple conflict at the School of Global Studies, involving Mikael Baaz, Katrina Gaber, Mona Lilja, and (previously) Niclas Lantz. The primary material underlying this paper consists of 20 openended and semi-structured in-depth interviews that were conducted in Cambodia in 2012 and 2014 with various civil society actors, journalists, civil servants, politicians, and other relevant stakeholders to the conflict. In addition, 42 interviews made in 2013 and 2015 in Thailand, with different civil society actors, have informed the analysis, even though these interviews are not directly cited in this paper. The latter interviews were conducted by Katrina Gaber on the Thai side of the borderland area (in Bhumisarol and Khantaralak, Sisaket Province) and in Bangkok. All the respondents were, in different regards, stakeholders in the temple conflict.

During all the interviews, the respondents were given the opportunity to address questions that they found relevant in order to contribute to a broader understanding regarding the various processes at work. In order to protect the safety of the respondents, their identities are not revealed in the paper.

The primary material also consists of other sources of information, including official documents, various media sites, blogs, as well as other internet resources. Such material is included in order to paint a broader picture of the PVT conflict and the resistance against it. Documentaries, as well as other forms of public and popular media expressions, including social media, potentially hold important information on the nature of the temple conflict and various related civil society-based activities. In the latter case, we have limited ourselves to English-language sources due to linguistic restraints.

This paper is also based on a mixture of secondary sources, which are mainly scholarly texts, and also includes reports produced by various governmental as well as nongovernmental actors and organizations. In addition, the study is built on a broader understanding of various democracy issues within the local context that were identified during frequent field studies in Cambodia between 1995 and 2014.

\section{A Short Historical Background of the PVT Conflict}

Historically, the PVT has been used in different ways as a means of underpinning and affirming the unity of the states and the construction of a national collective identity in both Cambodia and Thailand. The conflict between the two countries over the PVT reveals how monumental architecture continues to be associated with and is used to legitimize national conflicts. It also displays how history, or perhaps more correctly, the usage and construction of history, is vital. Overall, the temple conflict shows that there are strong bonds between matter (stones, building, and land) and (the constructions of) history, identity politics, and nationalism. The temple itself, as an artefact and representation, does not have a single or fixed meaning; the temple emerges in the material-discursive nexus in which the symbolic and matter entangle. 
Scholars usually date the Angkorean period between AD 802 and 1431. However, as argued by David Chandler, the two dates mark neither a beginning nor an end. Still, Chandler concludes that these dates are nevertheless useful since they pinpoint Cambodia's period of greatness (Chandler 2008; Lilja and Baaz 2016, p. 4). For long periods during these six centuries, the Khmer Empire was the most powerful state formation in Southeast Asia, and at its peak, it covered much of what is Cambodia, Thailand, Laos, and southern Vietnam today. The Khmers were great builders, and during the Angkor Empire, the landscape was filled with monumental temples, grand reservoirs, and canals as well as an extensive road network. The PVT was built from the ninth to the twelfth century by five successive Khmer dynasty kings. Most of the temple, however, was built during the first half of the twelfth century during the reign of Suryavarman I and Suryavarman II, who also built Angkor Wat (Chandler 2008; Lilja and Baaz 2016, p. 4). Given that the PVT was built during the time of the Angkor Empire, it is considered a key edifice of the empire's spiritual life and it is often described as bearing elements of various architectural styles given that several successive kings have modified the temple (Interview, UNESCO staff member, Phnom Penh, 2012).

The long construction period of the PVT indicates that the temple is unique to the Khmer Empire. 'Since a king generally built only one temple. It must have meant a way of controlling military power. Preah Vihear means a symbol of great emperor power, a significant monument with great value for the self-respect and pride of Cambodians' (Interview, UN employee, Phnom Penh, 2012). The uniqueness of the temple has made it an important reference point for actors who want to mobilize modern Cambodia by referring to the country's glorious past (Hinton 2006; Lilja and Baaz 2016, p. 4).

The Khmer's period of greatness, however, came to an end. After the Siamese invasion of Angkor in 1432, several centuries of decline and decay followed and Cambodia was ruled as a vassal state between Siam and Vietnam. ${ }^{1}$ In 1863, in order to avoid being transformed into a Thai-controlled area, Cambodia was turned into a French protectorate (see further Chandler 2008: Ch. 3-9; Corfield 2009, Ch. 1-3; Lilja and Baaz 2016, p. 5).

The current Thai and Cambodian border conflict, around the Preah Vihear temple, has its origin in a number of boundary agreements between France and Siam that were signed between 1904 and 1908. These agreements are, in turn, a response to the FrancoSiamese Treaty of 1893, which concluded a violent conflict between France and Siam in the same year. Together, the treaties established the boundaries of what eventually became Thailand, Cambodia, and Laos. By departing from the Franco-Siamese Boundary Treaty of 23 March 1907, the frontier regions were then mapped by French officers. The final maps showed that the PVT was on Cambodian soil and this was communicated to the Siamese Government in 1908. The Siamese Government, at that time, did not protest officially against the drawn boundary lines (International Court of Justice (ICJ) 1962; Strate 2013; Lilja and Baaz 2016, p. 5).

When France withdrew from Cambodia in 1953 Thailand established a police post just north of the PVT and hoisted the Thai flag over the ruin in 1954. In due course, this led to the new and independent Cambodian government turning to the International Court of Justice (ICJ) in 1959 to ask for assistance in solving the temple conflict with Thailand. In June 1962, the ICJ presented its judgment and ruled that the PVT belonged to Cambodia. The judgment was split (9-2) and Thailand reluctantly accepted it (ICJ 1962; Silverman 2010; St John 1994; Lilja and Baaz 2016, p. 5).

\footnotetext{
${ }^{1}$ Siam is the former name of Thailand.
} 
In 2008, UNESCO decided to list the PVT as a 'World Heritage' site, which provoked new conflict patterns. This time, the Thai protests did not focus on the temple per se, but rather on the still disputed $4.6 \mathrm{~km}^{2}$ of land surrounding the PVT (Silverman, 2010, pp. 4-5). Periodic eruptions of deadly violence have been the result of the dispute between Cambodia and Thailand. In 2011, Cambodia, therefore, once again turned to the ICJ to ask for assistance in interpreting the 1962 judgment. The 2013 ICJ decision affirmed the 1962 judgment that gave sovereignty of the temple to Cambodia as well as making some clarifications regarding the extent to which this sovereignty extended over the land surrounding the PVT. The 2013 decision refines the expression 'vicinity' that was used in the 1962 judgment by defining it as the whole promontory in which the temple is located. However, the promontory is just a small part of the $4.6 \mathrm{~km}^{2}$ of land that is still quarreled. By this, the ICJ has ultimately not ruled on the entire disputed area, but has left it to the two countries to resolve the border issue over the remaining land (International Court of Justice (ICJ) 2013; Lilja and Baaz 2016, p. 6; Ciorciari 2014). Both governments welcomed the decision and suggested talks to solve outstanding issues once and for all (CNN 2013).

There is currently very little interest in Cambodia for further confrontation over the land bordering the PVT. The political atmosphere in Thailand, however, has changed dramatically over the recent years and today it is very different from that of Cambodia. Following several political crises since 2008, which were on an overall level characterized by violent struggles between the so-called Red Shirts and Yellow Shirts, the Thai Army carried out a military coup in the country in May 2014. The opposition in Thailand prior to the coup, primarily the nationalist Yellow Shirts (or more formally: The People's Alliance for Democracy), strongly rejected the Cambodian sovereignty claims of the PVT and stated that the issue is unresolved and they have been using the PVT to undermine the Thai government since 2008 (Chachavalpongpun 2013; Lilja and Baaz 2016, pp. 6-7). In January 2013, the Alliance demanded, among other things, that the Thai government must:

(...) announce that Thailand regards the ICJ has no authority to make the interpretation and Thailand will not accept the ruling. [That the] government must point out that Thailand has not accepted the international court's jurisdiction since 1962. [That the] government must not observe the injunction of the ICJ that requires it to pull out troops and border patrol policemen from the disputed area. Instead, the government must rush to push Cambodians from the area around the temple (...) [and that the] Thai government must not return to being a party to the UNESCO World Heritage. (The Nation 2013)

The military leaders in Bangkok, who are supported by the Yellow Shirts, after the coup, accused Cambodia of secretly supporting the Red Shirts. The Thai military has also recently erected barbed wire in the vicinity of the PVT. This time, at least so far, the Cambodian response has been only to carry out peaceful protests (Thearith 2014). To conclude, the PVT still holds political force and one cannot rule out a new outbreak of violence in the future (Lilja and Baaz 2016, p. 7).

Over the years, the long history of Siamese imperialism in the region has been used by Cambodian leaders to create a narrative in regard to Thai claims to the PVT. According to Shane Strate, Thailand is described as the wolf and Cambodia is the lamb. In Thailand, however, the narrative is different (Strate 2013, pp. 41-43). Here, the country is described as the lamb, while France is described as the wolf. The PVT is portrayed as a fine that was paid to the colonial powers in order to remain a sovereign 
state. Or in other words, Thailand's leaders 'sacrificed a finger to save a hand' (Strate 2013, pp. 41-43; Lilja and Baaz 2016, p. 6). In Thailand, the PVT is associated with the legacy of western imperialism and, in particular, the territory that was 'lost' to the French imperialists.

The contradictory, mainstream narratives of Cambodia and Thailand described above could be understood, at least partly, with reference to the fact that Thailand has displayed characteristics of both colonizing and colonized power. Strate writes that 'The image of lost territories serves as a reminder of Western imperialism and also masks Thai neo-imperialist ambitions in Cambodia and Laos, presenting military aggression as an attempt to "recover what was lost" (Strate 2013, pp. 44-46). According to Alexander Hinton, a dominating discourse on Thailand in Cambodia is that of 'Thai thieves', who are always ready to 'rob' Cambodia (Hinton 2006). One of our respondents said: 'Cambodians look upon Thailand as a rapacious Thailand, always claiming territory from Cambodia. And historically, always claiming PVT and other Angkorian temples and look upon themselves as ancestors of the ancient Khmer culture. They have always laid claims to that, for hundreds of years. They have controlled the area for hundreds of years as well' (Interview, author, Phnom Penh 2012).

Moreover, in the interviews nationalism was often mention as a cause of the conflict. In 2012 a respondent said: 'The cause [of the temple conflict], the main cause is two things: the one is the political incongruences, and second is extreme nationalism' (Interview, civil-society representative, Phnom Penh, 2012). Another respondent argued: 'the Cambodian society (see the temple) as part of their heritage, cultural heritage, an intrinsic part of their identity. And you know because it has been contested it has become much more sensitive and more important, even more important than Angkor Wat. Because it is contested' (Interview, author, Phnom Penh 2012; Lilja and Baaz 2016, p. 6).

The above indicates that strong nationalism underlies the temple conflict in both Cambodia and Thailand. But, as put forward by Hinton, there are also people calling for peace and understanding (Hinton 2006, p. 468; Lilja and Baaz 2016, p. 7). Such discourses also surfaced in 2012, when several of our interviews contain alternative stories, which we interpret as resistance against more nationalistic discourses that fuel the temple conflict. Among other things, new understandings of the artefact that the temple constitutes, as well as the conflict parts, were promoted by our respondents in relation to the border conflict. We understand this as a resisting practice, the practice of (re)categorizing current mainstream narratives.

\section{Resistance and Civil Society from a Discursive Material Perspective}

The 'material turn' often departs from, and adds to, the 'linguistic turn'. In this, it is important to acknowledge different strands of 'post-structural' theory. Foucault, for example, who is often labelled as 'post-structural', embraces the importance of language while still emphasizing the role of matter and material space in the shaping of subjects. Among other things, matter predominates in Foucault's discussion of Bentham's Panopticon as an architectural configuration. Foucault also positions the body as the locus of productive forces: 
(we must) show how the deployments of power are directly connected to the body-to bodies, functions, physiological processes, sensations, and pleasures; far from the body having to be effected, what is needed is to make it visible through an analysis in which the biological and the historical are not consecutive to one another (...) but are bound together in an increasingly complex fashion in accordance with the development of the modern technologies of power that takes life as their objective. Hence, I do not envision a 'history of mentalities' that would take account of bodies only through the manner in which they have been perceived and given meaning and value; but a 'history of bodies' and the manner in which what is most material and most vital in them has been invested. (Foucault 1981)

While Foucault stressed the linguistic without 'throwing out' matter, there are also some 'extreme' strands of the linguistic turn. Power, in this view, is regarded as discursive regimes and what is sayable at all (Ferguson 1993, p. 124). From this perspective, we are raised into a language that limits what we can think or say. As Kathy Ferguson argues 'The power that linguistic feminism attributes to language resides not only in what gets said or who gets to talk, but in what is sayable at all' (Ferguson 1993, p. 124).

Many followers of the 'material turn' are skeptical of this extreme position of 'poststructural' theory. Still, as argued by Alaimo and Hekman (2008), the linguistic turn should not be rejected, but departed from and built upon. In line with this, we embrace both language and material when analyzing civil society-based peace-building resistance against the PVT conflict. We hereby acknowledge that the material is more than a passive social construction, but instead stands out as an 'agentic' force that interacts with and changes discourse (Alaimo and Hekman, 2008, pp. 4-7). Put in a different way, exploring the existence of a materiality can actually contribute to our understanding of the discursive production; this is due to the fact that various aspects of materiality can contribute to the development and transformation of discourses (Colebrook 2000; Grosz 1994). Karen Barad (2008) argues that the nature/material prevails within post-structuralism as a passive being, which is defined in relation to an active culture. She, however, argues that nature also affects discourses and has political consequences (Barad 2008). Thus, matter, in some senses, might be assigned agency, while it informs and shapes practices and current discursive truths.

Of particular interest to us are civil society-resistance practices. Various practices, which negotiate norms and discursive boundaries, are taking place in-between the subject and the material context. We would like to argue that there is no clear border between the subject and matter in a moment of resistance. The differences between the matter, practice, and subject are not 'fixed, absolute or inherent' (Lenz 2011). Consider, for example, Tahrir Square, in Cairo, Egypt, which has become a well-known symbol for the 'Arab Spring'. The square and the protesters are actively doing something to each other simultaneously. The material conditions of the square, its location, openness and grandness, all affect the interrelations that emerge inbetween the protesters and the square. The protesters bodies are adjusted to a range of material conditions - the square's generous surface area, its flatness, its structure, and the central location of the square. The traffic circle at the center of Tahrir Square and its closeness to important buildings - such as the Egyptian Museum, the building of the National Democratic Party headquarters, the Mogamma government building, and the Headquarters of the Arab League building - most likely contribute to why and how people move on the square. In addition, the square is easily accessible and is serviced by the Sadat Station of the Cairo Metro system. The material forces of the area's architecture, infrastructure, and cityscape interact with 
the bodies and minds of the protesters and provide them with what that they have to either work with or against (Lenz 2011). The demonstrations on Tahrir Square can be viewed as events or phenomena, which in Barad's terminology, emerge through different intra-actions (Barad 2008).

The above implies that we should abandon the constructed separateness between not only discourse and matter, but also between human resistance and the material conditions of this resistance (Lenz 2011). How civil society is constructed depends on, by extension, how certain borders or boundaries are established while we interpret the doings of civil society actors in the nexus between human practices and matter. In regard to the PVT, stones, land, architecture, legal documents, and various texts published on the internet are important material aspects for analyzing resistance. Bodies materialize as Thai or Cambodian, who act and interact in processes that entangle movements, spaces, things, and language.

Overall, what we understand as, for example, the Arab uprising is created and recreated in the assemblage of encounters and interrelations (Barad, 2008). Rather than considering the Egyptian, Cambodian, Thai, or any other civil society in a taken-for-granted manner, we should think of civil society (or a part of it) as emergences in the interaction between the subjects, practices, matter and various understandings of these interactions. If we do so, civil society becomes the result of our interpretations of multiple encounters, practices, materialities, and interrelations that are performed over time. Because, as Kate Weston points out, there can be no space without time. Put in a different way, every configuration of resistance is always simultaneously spatial and temporal — our interpretations of the world are always shaped in 'spacetime' (Weston 2002).

\section{Theoretical Point of Departure: Resistance, the Surplus, and Two Levels of Signification}

As stated above, this paper addresses how resistance, in the context of the temple, is articulated in relation to matter, current discourses, and the construction of history. The resistance that is in focus is subtle forms of resistance, which often turn out to be 'invisible' practices that take place behind the stage of public rebellions (Scott 1985). Such disguised 'everyday practices of resistance' are, however, to be considered as central, since they often focus on the construction of meaning. As Roland Bleiker argues, symbolism, poetic language, and storytelling can be highly relevant in terms of resistance and '(...) the most powerful practices of dissent (...) work in discursive ways, that is, by engendering a slow transformation of values' (Bleiker 2000). In line with this, resistance studies have mainly been preoccupied with immaterial cultural processes and intersubjective meaning systems. The field has been characterized by generally 'less than tangible' entities such as texts, signs, symbols, identity, and language (Törnberg 2013). However, as stated above, we should also take into consideration the physical and material entities and their potential 'agency'; that is, the ways in which matter is of importance in discursive production. We should thus highlight the central role of the material in the processes where discourses (of resistance) are constructed. Primarily, we are inspired by the idea that the material is more than a passive social construction, but instead stands out as an 'agentic' force that interacts with and changes discourses. Thus, we explore how the existence of materiality that entangles with resistance practices can actually contribute to the development and transformation of discourses (Colebrook 2000; Grosz 1994). 
In what follows, we look into one form of resistance in relation to the PVT conflict: (re)categorization. Here, resistance manifests in the negotiations of what people experience as generally held 'truths' by '(re)categorizing' the discourses. (Re)categorization denotes resistance that is played out as different stakeholders try to negotiate mainstream views on the temple conflict, which they regard as violent or repressive. Every interval of repetition of the discourse offers a place where, what seem to be experienced as, power-loaded truths regarding the temple could be challenged and/or changed. Overall, we understand resistance as a response to power (in this case, in the form of dominant, nationalistic discourses) practiced by people who either fight for themselves or for others who could be targeted in, or affected by, the temple conflict. The (re)categorization displayed in the analytical section below, is made possible in the nexus between the material and the discursive.

Before moving on to the analysis, we present some theoretical perspectives that contribute to our understanding of the practice of (re)categorization as a deconstructing strategy of resistance. To understand (re)categorization, we must understand categorization and its relationship with matter. Post-structuralist scholars, among them Stuart Hall, agree that people generally understand the world by classifying and organizing it into various symbolic orders. Food, for example, is separated and organized into 'raw' and 'cooked', 'vegetables', 'fruit', etc.; these are categories that are often considered to be natural to us. From this perspective, different foods are assigned different positions within a 'classificatory system' (Claude LéviStrauss in Hall 1997). This reasoning is further added to by Barad who views the world from a discursive-material perspective and embraces categories as a part of a different phenomenon that is constructed but still informed by an objectively existing reality (Barad 2008).

We take a slightly different approach than Barad. Foremost, we argue that embracing materiality is important when trying to understand the negotiations of different classificatory systems. By this, we display how matter is important for resistance by standing out as an agentic force, which opens up space for various discursive strategies. Moreover, by including matter into our analytical scheme, we also explore the overlaps and gaps that prevail in the meeting between discourses and matter. Often there is a gap or a surplus between the category and the real. Consider, for example, the concept 'women'. It has a certain meaning assigned to it and when we interpret the world, we tend to understand women from our understandings of a 'woman'. However, the world is more complex and richer than the concept or name 'woman' (the stereotype), which leaves us with remnants of reality that lie outside our conceptualizations of the real. There is a non-symbolized real that we fail to capture (Lilja 2016). Overall, the relationship between the 'naming' and reality is a complex one, where the real does not fit neatly into the symbolic space, which produces an effect of a non-symbolizable surplus (Edkins 1999).

Thus, there is often, not to say always, a gap between the meaning assigned to a name (for example, the descriptive features ascribed to a 'woman') and the object that has been named (the real woman). This 'surplus' or 'gap' might lead to the (re)categorization of the cultural order and its lived categories. For example, one of our respondents - a Cambodian womanblamed the fact that she was not married on the gap between her view of herself and the image of a 'Cambodian woman'. She said 'I am too intelligent to be a Cambodian woman; I cannot be a Cambodian woman' (Interview, Politician, Phnom Penh 2012). By not recognizing herself along the Cambodian discourses of femininity, the women located herself in a new category; neither as a 'man' nor a 'women'. As an 'in-between' representation, she (re)categorized the cultural order. Thus, matter might contribute to resistance, when things fail to fit into any category. This last observation is of great interest for our analysis. 
The relationship between matter and the symbolic could be even more nuanced by engaging with Paul Ricoeur's sketches of the material world (Ricoeur 1976). Even though Ricoeur, with his phenomenological hermeneutics, approaches reality from a slightly different angle than the above, we are still inspired by some of his notions of the real. Ricoeur, who differentiates between different levels of meaning making, argues that there is a literal signification of a phenomenon. However, often, this literal meaning is transgressed; there is an extension of meaning that is operative in every symbol (Ricoeur 1976). Ricoeur argues that the symbol functions as a 'surplus of signification' as there is more meaning assigned to the symbol than the literal signification. Or in other words, a poem about a sunrise describes more than a meteorological phenomenon. The poem, it can be argued, expresses an excess of signification that surpasses the literal connotation. Ricoeur explains the interpretation in the following way:

Only for an interpretation are there two levels of signification since it is the recognition of the literal meaning that allows us to see that a symbol still contains more meaning. This surplus of meaning is the residue of the literal interpretation. Yet for the one who participates in the symbolic signification there are really not two significations, one literal and the other symbolic, but rather a single movement, which transfers him from one level to the other and which assimilates him to the second signification by means of, or through the literal one. (Ricoeur 1976, p. 55)

Ricoeur argues that we do not separate the two levels of signification. For the participants in the communication, there are not really two significations-one literal and the other symbolic - but rather the reader is assimilating the latter signification by means of, or through, the former. Or in other words, there is always a literal significance (i.e. a close reading of the material facts, which entangle with our symbolic goods). Thus, as argued above, we must abandon the constructed separateness between discourse and matter. Categories and boundaries are established while we interpret, for example, resistance in the nexus between the symbolic 'order' and matter. Still, the possibility to move between Ricoeur's levels of significations creates the opportunity to resist certain 'truths', which fuel various conflict patterns. The material reality gives people the means and allows them to (re)categorize certain notions - in this case, various discursive goods that are assigned to the temple (Ricoeur 1976, p. 55).

\section{(Re)categorization as Resistance and Peace Building: An Analysis}

Below, we present some interpretations of what we label the 'peaceful resistance' of civil society actors, who act and interact in political processes that entangle with movements, spaces, things, and languages around the temple. Several of the civil society actors that we interviewed tried to frame the discourses regarding the PVT conflict in new and alternative ways. One respondent, for example, implied that the conflict is in some senses not a conflict, but just a result of current domestic politics in Thailand; she said:

If you ask me the problem is related to the political crises, especially in Thailand (...) Because the Thai side tried to politicize it. The pro-Thaksin government actually backed the Cambodian government in the process, but later on it changed. He couldn't stay any longer in the government. (Interview, civil-society representative, Phnom Penh 2012) 
The quote could be interpreted as an attempt to (re)categorize the PVT conflict from an international to an internal, national issue. Other attempts to redefine the conflict also appeared in our interviews. One respondent, for example, said 'I want to clarify that Thailand is not demanding the temple, but the land around the temple' (Interview, civil society representative, Phnom Penh, 2012). This is an interesting statement, since several other respondents did not distinguish between the land and the temple when discussing the temple conflict. For example, one respondent said:

The conflict between Thailand and Cambodia over Preah Vihear is actually not a new matter. (...) For me (the temple) is a symbol of this country, the Khmer empire. That is why it has become a symbol for the Cambodian so called 'prosperity period'. In other words, you can say that it symbolizes the Cambodian identity. (Leng Thearith, Research fellow, Phnom Penh)

In general, the respondents addressed the Thai-Cambodian conflict by putting up the temple as a node in which other discourses, in regard to the conflict, were organized around (Winther Jörgensen and Phillips 1999). Thus, the temple prevails as a privileged sign around which other words get their meanings. This is interesting, given that the ICJ awarded Cambodia sovereignty over the PVT more than 50 years ago. The judgment did not, as we know now, rule over the land immediately around the temple. Hence, what has been at stake in the latest stage of the PVT conflict has not been the temple per se, but rather a discussion about a related piece of land.

Taking into consideration the strong discourses around the PVT, the attempt to remove the temple from the conflict becomes interesting ('Thailand is not demanding the temple, but the land around the temple'). Even though the above respondent her/ himself probably not address her/his statement as resistance, we interpreted the statement as peace-building resistance, since the respondent seemingly negotiates nationalistic discursive constructions around the temple (by removing the temple from the conflict). The removal of the temple from the conflict displays a gap between the real object of the conflict (the land) and the discourses surrounding it. Put differently, a closer look into the issue would suggest that there is a gap between the matter - a piece of land - and the discourses that reinforce the conflict/temple couplet. In this, the move between the material and the discursive becomes compelling. The respondent above, in some senses, tries to use the surplus that emerges between the descriptive features of the conflict and the object of the conflict (the land) in order to deconstruct or 'solve' the current conflict. By emphasizing the land instead of the temple, the (re)categorization of the discourses about the PVT hereby holds a deconstructing potential. And, as argued above, it could also be seen as resistance as the (re)categorization appears as a response to power (i.e. dominant, nationalistic discourses in regard to the temple conflict).

Further attempts to separate matter from discourses - which reinforce the conflict/temple couplet - were seen in the interviews. One respondent, for example, suggested that one should distinguish between the people and the problem; or in other words, between the bodies and the meaning making. The civil society representative said as follows:

There is formalization between civil society in Cambodia and Thailand. We can contact each other immediately when there is a need, to address a problem. We have the freedom to communicate, to work together (...) Well, everyone believes that no problem can be solved by violence. And violent resolutions create suffering, so therefore we have to 
avoid that (...) The root cause of the problem is that we fight people, but we have to

fight the problem. (Interview, civil-society actor, Phnom Penh 2012)

The respondent is discussing peaceful strategies to solve the temple conflict. These strategies take place within a discursive-material context that is formed by the material artefact (that the temple constitutes) and the discourses that surround it. In the above quote, resistance is carried out by the respondent when (s)he chooses to make a distinction between the people and the problem. Again, it is resistance in the form of (re)categorizing, as it deconstructs previous interpretations about the PVT conflict. The new categorization challenges previous interpretations by offering new categories to depart from. The 'problem' is separated and disconnected from different bodies/actors ('we fight people, but we have to fight the problem'). Thus, solving the 'problem' does not involve a conflict with other people as they are removed from the 'problem'.

In order to further shed some light on the argument above, let us be inspired by what Stuart Hall calls different 'systems of representation'; the 'things in the world' are, he argues, interpreted by us (Hall, 1997). Thereafter, we map our interpretations with a set of concepts or categories. Or in other words, we use our concepts, or categories, and interpret the objects we see in the world; that is people, events, etc. We then have the discursive categories (or what might be called mental representations or concepts), which prevail as 'true' categories, as well as the things in the world - the people, objects or events - and through constructing a set of correspondences between these 'things in the world' and our conceptual maps, we give the objects meaning. People tend to map what they hear/see/experience and make matches between a more abstract mental representation and the factual artefact, movement, practice, and so on. Thus, the concepts - which might be about easily graspable things, such as chairs and plates, but also about war, love, or friendship - make us interpret the world according to certain discursive categories/'truths'.

However, in the case of the PVT conflict, some civil society actors seem to resist the dominating concepts, or conceptual maps, and seek to interpret the temple, the conflict, and its actors in new and alternative ways. Hall calls the expected interpretations and categorizations 'preferred meanings'. The writer of meaning often intends it to be interpreted in a certain way. The majority will also read the message in a very similar way to this 'preferred meaning'. However, there are those who resist and make different interpretations other than the preferred meanings (Lilja 2016; Skelton 2000). This is the case in relation to the PVT conflict, where one strategy is to (re)categorize different concepts, reinterpret the material conditions, and pinpoint the difference between the 'things in the world' and the prevailing conceptual maps. The physical and material entities of the temple then emerge as matter that matters in the discursive production. The material becomes an 'agentic' force that interacts with and changes discourses.

This kind of resistance of (re)categorization of civil-society actors was, for example, expressed in a column in the Bangkok Post. The columnist tried to shake the cultural order by reorganizing different layers of meaning. He argued:

I'm not a pacifist. There are reasons to fight. But 4.6 square kilometers of dirt is not one of them (...) If we give up the temple the dispute is over (...) Is not trade and commerce more important? Preah Vihear is just a pile of stones. (Voranai Vanijaka quoted in Strate 2013, p. 42)

The above-proposed discursive-materialistic approach provides us with a possibility to understand the kind of resistance that is being harbored in this (re)interpretation of the conflict. 
It is resistance through challenging nationalistic discourses by arguing that the $4.6 \mathrm{~km}^{2}$ surrounding the temple is not a lost body part of the Thai nation's body, but it is just ' 4.6 square kilometers of dirt'. This quote displays resistance by (re)categorization. The PVT is no longer interpreted and mapped as a holy, ancient artefact, but simply as a 'pile of stones'. Likewise, the land surrounding it, which is commonly associated with national identity, is now nothing but 'dirt'. We would like to propose that this (re)categorization is made possible because the columnist departs from matter and tries to make a close(r) 'empirical reading' of the PVT conflict. He is abandoning a more 'contextual reading' that involves various nationalistic ideas for a more 'literal meaning'. We do not know if the columnist actually visited the area and has seen the 'dirt' and the 'pile of stones' that he speaks of, but he still tries to depict the material facts of the temple without bringing in various symbolic goods, which might underpin the conflict.

To understand the above empirical close (and resisting) reading of the temple area, we should return to Ricoeur's different levels of meaning-making (Ricoeur, 1976). Ricoeur argues that there are two levels of signification - one literal and the other symbolic. The columnist, quoted above, seems to separate the literal connotation from the symbolic 'surplus', thereby, resisting the latter. This resistance is made possible as the material can be interpreted and (re)interpreted. In the quote above, the boundaries constituted through discursive-material practices are then (re)categorized through a literal reading of the land and temple. New norms are then created and imprinted into matter. Here, the stones of the Preah Vihear temple turn out to be agentic, as they contribute to how the temple is discussed and represented. The discourses around the temple are deconstructed while simultaneously being embraced as a symbolic surplus that exceeds the material fact of a 'pile of stone' (Barad 2008). This (re)categorization might be threatening to some civil society actors who strive hard to politicize the temple issue. Mary Douglas claims that people tend to protect the distinctive categories that they (we) arrange the world according to (Douglas, 1966, pp. 33-41).

In the above quote, the columnist compares his literal interpretation with the general view of the temple conflict in order to deconstruct the latter. This can be understood through the concept of 'concretism' (Lilja 2016), which denotes how certain representations are experienced as more concrete; that is, as more applicable, understandable, detailed, or practical. These more concrete representations then make us experience the discourses as more graspable and comprehendible than before.

Among its impacts, concretism strengthens discourses by exemplifying and/or repeating a more abstract discourse/notion with concrete representations. The ability of concretism to make complex matters more understandable/concrete can be illustrated by the way in which maps reduce countries, states, and infrastructure into well-arranged images, thereby visualizing nationalistic discourses and reinforcing them (Lilja 2016; Trenter 2000). Maps, thereby, stand out as more concrete representations, which make the discourses about nations, states, and countries more graspable, and thereby, strengthen these discourses.

The above implies that discourses might be strengthened by more concrete representations. However, in the above quote about the PVT, the opposite happens. Instead of strengthening the nationalistic discourses around the PVT, the columnist uses the very concrete representation of a 'pile of stone' to oppose and deconstruct the general 'truths' about the temple. The columnist makes a close, empirical reading of what we would see if watching the temple. Moreover, this reading contradicts the more general discourses that circulate around the temple. This usage of a literal reading of the temple - and the very concrete representation this reading suggests - must be seen as resistance against 
power-loaded and nationalistic discourses. The resistance is made possible by the ability to approach matter without bringing in various discursive constructions that surround it. Agency is then made possible, as there are different levels of interpretations in the nexus between the material and the discursive.

The 'new' concept, which is created in the attempts to (re)categorize the prevailing cultural order, also needs to be critically examined. Consider, for example, the columnist who is quoted above. His concept of 'dirt' is probably a very narrow reading of the landscape of the PVT, which consists of plants, stones, shades, trees, and dirt. This reductiveness is probably made to emphasize the main points that are argued by the columnist in regard to the temple, thus, being informed by the respondents' attempt to resist.

\section{Conclusion}

The field of resistance studies does not often explicitly embrace the material. In this paper, we seek to respond to this challenge by discussing practices of resistance in a discursive-material context. Departing from this discursive-materialistic approach contributes to our understanding of the resistance that is played out in relation to the PVT conflict. Resistance of various civil society actors is taking place in-between the subject and the material context. There is no clear border between the subject and matter in a moment of resistance; different material circumstances interact with the bodies and minds of the subjects, which provide them with the conditions that they have to either work with or against. The material and various discursive categories interact and shape different forms of resistance (i.e. practices used to negotiate what people experience as generally held 'truths').

In the analysis, we show how (re)categorizations can be interpreted as resistance practices in regard to the temple. Overall, we display how the characteristics of the discursive-material nexus make resistance, in the form of (re)categorization, possible. Among other things, there is (often) a gap or a surplus between the category and the real. This 'surplus' or 'gap' might provide agents with the possibility to resist and (re)categorize the cultural order by bringing in, or displaying, aspects of the real other than those accepted/included in the current categorization. Thus, matter might contribute to resistance when things fail to fit into any category. Or in the case of the Preah Vihear temple, different civil society actors choose to interpret the temple (the real) in an empirically close, or literal, way that abandons a more 'contextual reading', which involves different nationalistic discourses. In this, some of the above practices of (re)categorization can be seen as deconstructing moves that draw upon the surplus between meaning and matter.

Overall, the analysis of (re)categorization as resistance implies that in order to understand how resistance occurs due to material aspects, we must embrace that the material is more than a passive social construction, but instead stands out as an 'agentic' force that interacts with and changes discourses. Various aspects of materiality contribute to the development and transformation of discourses. Or in other words, the matter of the temple contributes to the discourses of the 'temple'.

Acknowledgments We would like to thank Katrina Gaber and Niclas Lantz for providing valuable input to the project. We would also like to express our sincere gratitude to the anonymous reviewers for their very helpful comments. 
Conflicts of Interest There are no potential conflicts of interest in regard to this article.

Consent of the Interviewees We have obtained the informed consent of the interviewees and we will protect their personal data.

Ethical Approval All procedures performed in studies involving human participants were in accordance with the ethical standards of the institutional and/or national research committee and with the 1964 Helsinki Declaration and its later amendments or comparable ethical standards.

Open Access This article is distributed under the terms of the Creative Commons Attribution 4.0 International License (http://creativecommons.org/licenses/by/4.0/), which permits unrestricted use, distribution, and reproduction in any medium, provided you give appropriate credit to the original author(s) and the source, provide a link to the Creative Commons license, and indicate if changes were made.

\section{References}

Alaimo, S., \& Hekman, S. (2008). Introduction: emerging models of materiality in feminist theory. In S. Alaimo \& S. Hekman (Eds.), Material feminism. Bloomington: Indiana University Press.

Barad, K. (2008). Posthumanist performativity: toward an understanding of how matter comes to matter. In S. Alaimo \& S. Hekman (Eds.), Material feminism. Bloomington: Indiana University Press.

Bleiker, R. (2000). Popular dissent, human agency, and global politics. Cambridge: Cambridge University Press. Chachavalpongpun, P. (2013). Dispute of Preah Vihear Temple is taken up, threatening to revive thai nationalistic fervor. The Japan Times. Retrieved from http:/www.japantimes.co.jp/opinion/2013/04/28 /commentary/world-commentary/dispute-over-preah-vihear-temple-is-taken-up-threatening-to-revive-thainationalistic-fervor/\#.VEY8S4uUeiY/.

Chandler, D. (2008). A history of Cambodia. Boulder: Westview Press.

Ciorciari, J. D. (2014). Thailand and Cambodia: the battle for Preah Vihear. Retrieved from http://spice.stanford. edu/docs/thailand_and_cambodia_the_battle_for_preah_vihear/.

CNN. (2013). Thai villagers return after verdict on disputed Preah Vihear temple. Retrieved from http://edition. cnn.com/2013/11/12/world/asia/thailand-cambodia-temple/.

Colebrook, C. (2000). Introduction. In I. Buchanan \& C. Colebrook (Eds.), Deleuze and feminist theory. Edinburgh: Edinburgh University Press.

Corfield, J. (2009). The history of Cambodia. Oxford: Greenwood Press.

Douglas, M. (1966). Purity and danger. London: Routledge.

Edkins, J. (1999). Poststructuralism and international relations. Boulder: Lynne Reiner.

Ferguson, K. (1993). The man question: visions of subjectivity in feminist theory. Berkeley: University of California Press.

Foucault, M. (1981). The history of sexuality, volume 1: an introduction. Harmondsworth: Penguin.

Grosz, E. (1994). Volatile bodies: towards a corporeal feminism. Bloomington: Indiana University Press.

Hall, S. (1997). Representation: cultural representation and signifying practices. London: Sage.

Hinton, A. (2006). Khmerness and the Thai 'Other': violence, discourse and symbolism in 2003 anti-Thai riots in Cambodia. Journal of Southeast Asian Studies, 37(3), 445-468.

International Court of Justice (ICJ). (1962). Temple of Preah Vihear (Cambodia v. Thailand). Retrieved from http:/www.icjcij.org/docket/index.php?p1=3\&p2=3\&case=45\&p3=4/.

International Court of Justice (ICJ). (2013). Request for interpretation of the judgment of 15 June 1962 in the case concerning the Temple of Preah Vihear (Cambodia v. Thailand). Retrieved from http://www.icj-cij. org/docket/index.php?p1=3\&p2=3\&case $=151 \& \mathrm{p} 3=0 /$.

Kasetsiri, C., Sothirak, P., \& Chachavalpongpun, P. (2013). Preah Vihear: a guide to the Thai-Cambodian conflict and its solutions. Bangkok: White Lotus.

Khmerization. (2014). Cambodia says 40 Thai troops cross border in temple feud. Retrieved from http://khmerisation.wordpress.com/2008/07/15/cambodia-says-40-thai-troops-cross-border-in-temple-feud/.

Lenz, H. T. (2011). Investigating learning, participation and becoming in early childhood practices with a relational materialist approach. Global Studies of Childhood, 1(1), 36-50.

Lilja, M. (2016). Resisting Gendered Norms Civil Society, the Judicial and Political Space in Cambodia. Routledge, London and New York

Lilja, M. \& Baaz, M. (2016). Theorising "peace-building” resistance: constructions of time and different temporalities at play in the Preah Vihear temple-conflict. European Journal of Cultural and Political Sociology. doi:10.1080/23254823.2016.1203812. 
Nation, the. (2013). Phatarawadee Phataranawik. Retrieved from http:/www.nationmultimedia. com/life/History-is-always-present-30208654.html/.

Ricoeur, P. (1976). Interpretation theory: discourse and the surplus of meaning. Fort Worth: The Texas Christian University Press.

Scott, J. C. (1985). Weapons of the weak: everyday forms of peasant resistance. New Haven: Yale University Press.

Silverman, H. (2010). Border wars: the ongoing temple dispute between Thailand and Cambodia and UNESCO's World Heritage List. International Journal of Heritage Studies, 17(1), 1-21.

Skelton, T. (2000). Jamaican Yardies on British television: dominant representations, spaces for resistance? In J. Sharp et al. (Eds.), Entanglements of power: geographies of domination/resistance. London: Routledge.

St John, R. B. (1994). Preah Vihear and the Cambodia-Thailand Borderland. IBRU Boundary and Security Bulletin, January, 64-68.

Strate, S. (2013). A pile of stones? Preah Vihear as a Thai symbol of national humiliation. South East Asia Research, 21(1), 41-68.

Thearith, L. (2014). The Cambodian fallout from Thailand's coup. EastAsia Forum, Retrieved from http://www. eastasiaforum.org/2014/06/27/the-cambodian-fallout-of-thailands-coup/\#more-42300/.

Trenter, C. (2000). 'And Now-Imagine She's White': Postkolonial Historiebeskrivning. In P. Aronsson (Ed.), Makten över Minnet: Historiekultur i Förändring. Studentlitteratur: Lund.

Törnberg, A. (2013). Resistance Studies and the Material Turn. Paper presented at the Resistance Studies Seminar. School of Global Studies: University of Gothenburg.

Weston, K. (2002). Gender in real time: power and transience in a visual age. London: Routledge.

Winther Jörgensen, M., \& Phillips, L. (1999). Diskursanalys som Teori och Metod. Lund: Studentlitteratur. 